creating its institutions of laws, religion, and learning. It was the establishment of viceroyalties, convents and a cathedral, two universities - the most notable being Santo Tomás de Aquino - and the flourishing of arts and literature during the 16th and early 17th century that earned Hispaniola the title of 'Athena of the New World.' The Spanish language permeated those institutions from which it spread, making Hispaniola the cradle of the Spanish spoken in the Americas.

Unlike the Spanish of Peru and Mexico, which co-existed with native Amerindian languages, Dominican Spanish received little influence from the decimated Tainos, whose Arawak-based language disappeared, leaving a few recognizable words, such as maiz 'maize' and barbacoa 'barbecue'. The 17th century saw the French challenge Spain's hegemony by occupying the western side of the island, which they called Saint Domingue and later became the Republic of Haiti. Spain continued ruling the eastern part under the name of Santo Domingo, changed subsequently to Dominican Republic by the independence movement, reserving Santo Domingo for the main city. Both powers were deeply engaged in the slave trade, which brought Spanish into contact with a variety of African languages. Dominican Spanish also inherited many words and a handful of phonetic and morphological traits that are attributable to African influence.

Like other dialects, Dominican Spanish transforms syllable-final /r/ and /1/ and word-final /n/ of mar 'sea', falta 'fault', and sin 'without' into [1], [r], and [n] respectively, so that they are pronounced as mal, far, and sing. Typical to the northern Cibao region, and not found elsewhere in the Hispanic world, is the mutation of final $/ \mathrm{r} /, / \mathrm{l} /$ into the [i] sound. Mar and falta are pronounced as mai and faita, both sounding like $m y$ and fight. Final /s/ also undergoes alterations ranging from the aspiration noticeable in costa 'coast', rendered as cohta, with a sound similar to the $b$ in $h o t$, to total elimination, producing in popular speech cota, for the word above. This loss has led many uneducated speakers to restructure their plural, so that instead of the expected cotas 'coasts', with $-s$ denoting plurality, they have created a new plural with -se, as in cótase.

Dominican syntax tends to prepose pronouns in interrogative questions. As an alternative to the standard qué quieres tú? 'what do you want?', carrying an obligatory, postverbal tú 'you', speakers say qué tú quieres?. The latter sentence further shows retention of pronouns, which most dialects may omit. Frequently found in Dominican is the repetition of double negatives for emphatic purposes, arguably of Haitian creole descent. In responding to 'who did that?', many speakers will reply with a yo no sé no 'I don't know, no'.

Notwithstanding the numerous changes to its grammatical system, and the continuous contact with the English of a large immigrant population residing in the United States, Dominican Spanish has remained faithful to its Hispanic heritage. There exists a regulated normative linguistic system, taught in schools and reproduced by the mass media and literary works, that eight million speakers aspire to learn and imitate. Its mastery, along with its own Dominicanness, have engendered the likes of the humanist Pedro Henríquez Ureña, and the shortstory writer Juan Bosch, who have come to occupy a place of distinction in Hispanic letters.

See also: Pidgins and Creoles: Overview; Spanish.

\section{Bibliography}

Bosch J (1991). De Cristóbal Colón a Fidel Castro: el Caribe, frontera imperial. Santo Domingo: Corripio.

Enciclopedia ilustrada de la República Dominicana (11 vols) (2003). Santo Domingo: Eduprogreso.

Henríquez Ureña P (1945). Literary currents in Hispanic America. Cambridge, MA: Harvard University Press.

Lipski J M (1994). Latin American Spanish. London/New York: Longman.

\title{
Donkey Sentences
}

P A M Seuren, Max Planck Institute for Psycholinguistics, Nijmegen, The Netherlands

(c) 2006 Elsevier Ltd. All rights reserved.

The problem of 'donkey sentences' occupies a prominent place in the logical analysis of natural language sentences. The purpose of logical analysis of sentences is to assign them a structure suitable for logical calculus - that is, the formal derivation of entailments. Some variety of the language of predicate calculus (LPC) is normally used for logical translations.

In LPC, a term in a proposition that has a truth value must either be an expression referring to an individual (or a set of individuals) that actually exists 
or be a bound variable. Modern predicate calculus is essentially extensional: truth values are computed on the presumption that term referents actually exist, so that it allows in all cases for substitution of coextensional constituents salva veritate. Intensional or virtual objects - objects that have merely been thought up but that lack actual existence - have no place in modern logic, just as they have no place in Quine's 'desert landscape' ontology, which has gained currency in large sections of Anglo-Saxon philosophy. That being so, modern logic has no choice but to posit that any argument term of a predicate in a proposition that has a truth value either refers to an actually existing object or is a bound variable ranging over such objects.

Since in natural language one often encounters expressions that have the appearance of being referring argument terms but in actual fact fail to refer such as the famous sentence in Bertrand Russell's (1905) article The present king of France is bald Quine (1960) started a "program of elimination of particulars" aimed at reformulating natural language sentences exclusively in terms of the quantificational language of modern predicate calculus, without any referring terms. Thus, for Quine and large sections of the logical community, LPC bans all definite terms and allows only for variables in argument positions.

This, however, will not do for natural language, which has sentences that express purely extensional propositions and yet contain terms that neither refer to an actually existing object nor allow for an analysis as bound variable. These are the so-called donkey sentences. The fact that natural language resists analysis in terms of LPC constitutes the problem posed by the donkey sentences.

The currency of the term 'donkey sentences' originates with the British philosopher Peter Geach, whose discussion of certain sentences, all about donkeys, awakened the interest of modern logicians (Geach, 1962). Geach did not mention - apart from a token reference (1962: 116) to "another sort of medieval example" - that he took his cue from Walter Burleigh (c.1275-after 1344), who introduced donkey sentences in the context of supposition theory, the medieval equivalent of reference theory. In Burleigh (1988: 92), written around 1328, one finds this example:

(1) Omnis homo habens asinum videt illum. ('Every man owning a donkey sees it.')

Burleigh's problem had nothing to do with LPC, which did not yet exist. His problem was of a different nature. Having noticed that there exist what we now call bound variable pronouns, as in (2), and having stated that these may never take as antecedent a constituent of the same clause ('propositio categorica'), he presented (1) as an apparent counterexample, since the pronoun illum takes as antecedent asinum, which stands under the same verb (videt) and is thus in the same clause.

(2) All boys expected that the dog would bite them.

His answer was that the antecedent of illum, i.e., asinum, is not a main constituent of the same clause but a constituent of a subordinate predication, i.e., habens asinum ('owning a donkey').

Geach (1962) discussed the same problem: how to account for the antecedent relation when the antecedent occurs in a relative clause contained in a complex predicate. It stands to reason, he said (1962: 117), to treat man who owns a donkey in the sentences (3a) and $(3 \mathrm{~b})$, which he considered contradictories, as a complex predicate "replaceable by the single word 'donkey-owner'." But if we did that, (3a) and (3b) "become unintelligible ... because 'it' is deprived of an antecedent":

(3a) Any man who owns a donkey beats it.

(3b) Some man who owns a donkey does not beat it.

A solution could conceivably be found in rewording these sentences as (4a) and (4b) (1962: 117):

(4a) Any man who owns a donkey, owns a donkey and beats it.

(4b) Some man who owns a donkey owns a donkey and does not beat it.

Yet, he says, whereas (3a) and (3b) are contradictories, at least according to native speakers' intuitions, (4a) and (4b) are not (1962: 118):

[F]or both would be true if each donkey-owner had two donkeys and beat only one of them. Medieval logicians would apparently have accepted the alleged equivalences; for they argued that a pair such as [(3a)] and $[(3 b)]$ could both be true ... and were therefore not contradictories. But plainly [(3a)] and [(3b)], as they would normally be understood, are in fact contradictories; in the case supposed, [(3b)] would be true and [(3a)] false.

The "medieval logicians" Geach argues against are in fact Walter Burleigh, who added the following comment to his discussion of (1), thereby denying that (3a) and (3b) are contradictories (1988: 92-93; translation mine):

It follows that the following are compatible: 'Every man owning a donkey sees it' and 'Some man owning a donkey does not see it'. For assuming that every man owns two donkeys, one of which he sees and one of 
which he does not see, then it is not only true to say 'Every man owning a donkey sees it', but also to say 'Some man owning a donkey does not see it'. In the same way, suppose that every man who has a son also has two sons, and that he loves the one but hates the other, then both the following are true: 'Every man who has a son loves him' and 'Some man who has a son does not love him'.

Geach's own solution was to analyze a relative clause within a predicate as an implication under universal, and a conjunction under existential quantification, as in (5).

(5a) Any man, if he owns a donkey, beats it.

(5b) Some man owns a donkey and he does not beat it.

This "is quite unforced and does give us a pair of contradictories, as it ought" (Geach, 1988: 92-93). Yet Geach apparently failed to realize that $(5 \mathrm{a})$ does not translate into modern predicate logic. Its translation would have to be something like (6), which contains the free variable $y$ in Beat $(x, y)$

(6) $\forall \mathrm{x}[\operatorname{Man}(\mathrm{x}) \rightarrow[\exists \mathrm{y}[\operatorname{Donkey}(\mathrm{y}) \wedge \mathrm{Own}(\mathrm{x}, \mathrm{y})] \rightarrow$ $\operatorname{Beat}(\mathbf{x}, \mathbf{y})]]$

Had he realized that, he would have hit on the donkey sentences problem as it lives in modern formal semantics.

Geach strengthened his putative solution by arguing (1972: 115-127) that a sentence like (7) should not be translated as a conjunction of two propositions - as $\mathrm{A} \wedge \mathrm{B}$ - but rather as a single quantified proposition with it translated as a bound variable, as in (8).

(7) Smith owns a donkey and he beats it.

(8) $\exists x[\operatorname{Donkey}(\mathrm{x}) \wedge \operatorname{Own}($ Smith, $\mathrm{x}) \wedge$ Beat $($ Smith, $x)]$

His argument amounts to saying that $\mathrm{A} \wedge \mathrm{B}$ and $\mathrm{A} \wedge \neg \mathrm{B}$ cannot be true at the same time, whereas (7) and (9) can. All it takes is for Smith to own two donkeys, only one of which he beats.

(9) Smith owns a donkey and he does not beat it.

Therefore, Geach argues, the logical translation (8) is correct, since it is compatible with (10), which simply posits a second ass, owned by Smith but not beaten by him

$$
\text { (10) } \begin{aligned}
& \exists x[\operatorname{Donkey}(\mathrm{x}) \wedge \operatorname{Own}(\operatorname{Smith}, \mathrm{x}) \wedge \\
& \neg \operatorname{Beat}(\text { Smith, } \mathrm{x})]
\end{aligned}
$$

This analysis, however, cannot be correct, as pointed out in Seuren (2001: 316-318), since it lacks generality in view of cases like (11). (11a) Smith must own a donkey, and he may beat it.

(11b) I believe that Smith owns a donkey, and I fear that he beats it.

(11c) This made Smith own a donkey and kept him from beating it.

No analysis of the type shown in (8) or (10) is applicable here, since they either require large scope for $a$ donkey, which is contrary to what these sentences mean, or have to place the second operator (may, fear, keep) in the scope of the first (must, believe, make), which again is not what these sentences mean. Geach's analysis thus comes to nothing.

All this, however, is still beating about the bush. The real problem shows up in (12):

(12a) Every farmer who owns a donkey feeds it.

(12b) If Smith owns a donkey, he feeds it.

(12c) Either Smith does not own a donkey or he feeds it.

In the standard logical analysis of if and or, they come out as true if Smith owns no donkey. But then it cannot be translated as a referring expression (the donkey), as it lacks a referent. It should therefore be translatable as a bound variable. But that, too, turns out to be impossible. Universal quantification, proposed by Quine (1960: 139) and many others as a solution, again falls foul of possible intervening operators, as in (13) (see Seuren, 1998).

(13a) If Smith wants to own a donkey he must promise to feed it.

(13b) Either Smith no longer owns a donkey or he still feeds it.

There thus seems to be a hard core of sentences resisting translation into LPC. They contain definite expressions, preferably pronouns, that are neither referring expressions nor bound variables.

Also, these pronouns behave like referring expressions anaphorically linked to an antecedent, and not like bound variable pronouns. The former allow for substitution by a lexical noun phrase ('epithet anaphora'); the latter do not. Thus, it in (14a), (14b), and $(14 \mathrm{c})$ can be replaced by, for example, the animal, without much change in meaning, but it in (14d), which represents a bound variable, does not allow for such substitution.

(14a) Smith owns a donkey and he feeds it/the animal.

(14b) If Smith owns a donkey he feeds it/the animal.

(14c) Either Smith does not own a donkey or he feeds it/the animal.

(14d) Every donkey owned by Smith expects that he will feed it/*the animal. 
Donkey pronouns, therefore, behave like referring expressions even though they are not allowed to do so under the statutes of current logic. Kamp and Reyle (1993) recognized the fundamental nature of this problem and proposed a radical departure from standard notions and techniques of semantic interpretation. They defended an analysis whereby the donkey pronouns and other definite expressions do not refer directly to entities in the world at hand but instead denote mental representations of possible real-world entities. In this theory, known as Discourse Representation Theory, the mechanism of reference is mediated by a cognitive system of mental representations whose relation to any actual world is a matter of independent concern. This halfway station of mental representations creates some extra room for a semantic account of donkey sentences. Even so, however, standard logical analyses are inadequate for natural language. What logic will do better justice to the facts of language is still an open question. Groenendijk and Stokhof (1991) was an attempt at answering that question.

See also: Anaphora, Cataphora, Exophora, Logophoricity; Constants and Variables; Discourse Representation Theory; Dynamic Semantics; Propositional and Predicate Logic: Linguistic Aspects.

\section{Bibliography}

Burleigh W (1988). Von der Reinheit der Kunst der Logik. Erster Traktat. Von den Eigenschaften der Termini. (De puritate artis logicae. De proprietatibus terminorum). [Translated and edited by Peter Kunze, with introduction and commentary]. Hamburg: Felix Meiner Verlag.

Geach P T (1962). Reference and generality: an examination of some medieval and modern theories. Ithaca, NY: Cornell University Press.

Geach P T (1972). Logic Matters. Oxford: Blackwell.

Groenendijk J \& Stokhof M (1991). 'Dynamic predicate logic.' Linguistics and Philosophy 14, 39-100.

Kamp H \& Reyle U (1993). From discourse to logic: introduction to model-theoretic semantics of natural language, formal logic and discourse representation theory. Dordrecht: Kluwer.

Quine W V O (1960). Word and object. Cambridge, MA: MIT Press.

Russell B (1905). 'On denoting.' Mind 14, 479-493.

Seuren P A M (1998). 'Towards a discourse-semantic account of donkey anaphora.' In Botley S \& McEnery T (eds.) New approaches to discourse anaphora: proceedings of the second colloquium on Discourse Anaphora and Anaphor Resolution (DAARC2). University Centre for Computer Corpus Research on Language, Lancaster University. Technical Papers, Vol. 11, Special Issue. 212-220.

Seuren P A M (2001). A view of language. Oxford: Oxford University Press.

\section{Dorian, Nancy C. (b. 1936)}

L K Obler, CUNY Graduate Center, New York, NY, USA

(C) 2006 Elsevier Ltd. All rights reserved.

Nancy Currier Dorian has been at the forefront of studies of language death and minority languages, authoring several books and over 50 articles on the topic since her seminal article, 'Grammatical change in a dying dialect,' was published in Language in 1973. Starting out with the study of phonology in the dialect, she has extended her study of language death to the full range of linguistic phenomena, including lexical, morphological, and syntactic aspects, and contributed importantly in the area of sociolinguistics. In addition to her articles in the journal Language, she has contributed to the journals Word, The International Journal of Bilingualism, Language in Society, Applied Psycholinguistics, International Journal of the Sociology of Language, and Scottish Gaelic Studies. A book, currently in preparation, expands on her 1994 Language article on personally patterned variation in East Sutherland Gaelic (Gaelic, Scots), demonstrating that the same phenomenon occurs in a variety of unstandardized minority language communities.

Dorian is Professor Emeritus of Linguistics in German and Anthropology at Bryn Mawr College, where she taught from 1965 to 1989 , chairing the Department of German for three years between 1977 and 1983 and the Bi-College Department of German at Bryn Mawr and Haverford Colleges from 1986 to 1989.

Completing her undergraduate degree in German summa cum laude at Connecticut College for Women, she received a Fulbright Award to study linguistics and anthropology at the University of Bonn and the Free University of Berlin. She then studied linguistics at Yale and the University of Michigan, receiving her Ph.D. at the latter in 1965.

Dorian conducted fieldwork on East Sutherland Gaelic over the course of numerous extended visits between 1963 and 1978, resuming this work in the 